\title{
Genetic analysis of a tetracycline resistance element from Clostridium difficile and its conjugal transfer to and from Bacillus subtilis
}

\author{
Peter Mullany,* Mark Wilks, Ian Lamb, Chris Clayton, Brendan Wren \\ and SOAD TABAQCHALI
}

Department of Medical Microbiology, St Bartholomew's Hospital Medical College, West Smithfield, London ECIA $7 B E$, UK

(Received 8 December 1989; revised 5 March 1990; accepted 12 March 1990)

\begin{abstract}
A tetracycline resistance (Tcr) determinant from Clostridium difficile strain 630 was cloned into the Escherichia coli plasmid vector pUC13. The resulting plasmid pPPM20, containing an insert of $3.4 \mathrm{kbp}$, was mapped and a $1.1 \mathrm{kbp}$ SacI-HindIII fragment wholly within the Tcr $\mathrm{C}^{\mathrm{r}}$ gene was identified. Dot-blot hybridization studies with the $1 \cdot 1 \mathrm{kbp}$ fragment showed that the $\mathrm{Tc}^{\mathrm{r}}$ gene belonged to hybridization class $\mathrm{M}$. Tcr could be transferred between C. difficile strains and to Bacillus subtilis at a frequency of $1^{-7}$ per donor cell. The element could be returned from $B$. subtilis to $C$. difficile at a frequency of $10^{-8}$ per donor cell. This is the first demonstration of $C$. difficile acting as a recipient in intergeneric crosses. DNA from $C$. difficile transconjugants digested with $E c o R V$ always has two hybridizing fragments of 9.5 and $11.0 \mathrm{kbp}$ when probed with pPPM20. DNA from $B$. subtilis transconjugants digested with $E c o R V$ produced one hybridizing band of variable size when probed with pPPM20. The behaviour of the element was reminiscent of the conjugative transposons. Therefore we compared the element to the conjugative transposon Tn916. The HincII restriction maps of the two elements differed and no hybridization was detected to oligonucleotides directed to the ends of Tn916. However, the elements do have some sequence homology, detected by hybridization analysis.
\end{abstract}

\section{Introduction}

Clostridium difficile has been shown to be the most important cause of antibiotic-associated pseudomembranous colitis and antibiotic-associated diarrhoea (Larson \& Price, 1977; George et al., 1978; Bartlett et al., 1978). Resistance to antibiotics may also play a significant role in the development of the disease, as multiply resistant strains are often responsible for nosocomial outbreaks of $C$. difficile-associated disease (Pierce et al., 1982; Wust et al., 1982).

Resistance to tetracycline and macrolide antibiotics is known to be transferable between strains of $C$. difficile; and the transfer of tetracycline resistance $\left(\mathrm{Tc}^{\mathrm{r}}\right)$ has been found to be independent of the transfer of other antibiotic resistances (Wust \& Hardegger, 1983). Hybridization studies indicated that the transferable $\mathrm{Tc}^{\mathrm{r}}$ element contains sequences homologous to $95 \%$ of the conjugative transposon $\mathrm{Tn} 916$, which carries a $\mathrm{Tc}^{\mathrm{r}}$ gene of hybridization class M (Hachler et al., 1987a). Conjugative transposons are widespread in Grampositive bacteria and are important in the dissemination of antibiotic resistance genes in many Gram-positive genera (for a review see Clewell \& Gawron-Burke, 1986).

This paper describes the cloning and partial genetic and physical characterization of the $C$. difficile $\mathrm{Tc}^{r}$ element.

\section{Methods}

Bacterial strains and plasmids. All bacterial strains and plasmids used in this study are shown in Table 1.

Growth media. Clostridial strains were grown in pre-reduced Nakamura broth (Nakamura et al., 1981) or on Wilkins-Chalgren agar (Oxoid) and incubated at $37^{\circ} \mathrm{C}$ for $18 \mathrm{~h}$ under anaerobic conditions. All other strains were grown in Luria-Bertani broth or on Luria-Bertani agar (Maniatis et al., 1982).

DNA preparation. $C$. difficile and $B$. subtilis genomic DNA was prepared by a method developed in this laboratory (Wren \& Tabaqchali, 1987). Plasmid DNA from E. coli was prepared by the method of Birnboim \& Doly (1979).

Construction and screening of a $C$. difficile genomic library. C. difficile genomic DNA was partially cleaved with Sau $3 \mathrm{AI}$ and fragments between 2 and $10 \mathrm{kbp}$ were pooled. The fragments were ligated into the lacZ gene of BamHI-cleaved pUC13 plasmid DNA and transformed into competent $E$. coli JM109 cells by the method of Hanahan (1985). 
Table 1. Bacterial strains and plasmids

\begin{tabular}{|c|c|c|}
\hline Bacterial strains & Genotype and/or phenotype* & Source or reference \\
\hline \multicolumn{3}{|l|}{ C. difficile } \\
\hline $\mathrm{C}$ & $\mathrm{Tc}^{\mathrm{s}}$ Rif $^{\mathrm{s}}$; PAGE type strain & Tabaqchali et al. (1984) \\
\hline D & Tc $^{s}$ Rifs; PAGE type strain & Tabaqchali et al. (1984) \\
\hline 630 & $\mathrm{Tc}^{\mathrm{r}} \mathrm{Rif} \mathrm{s}^{\mathrm{s}} ; \mathrm{Tc}^{\mathrm{r}}$ donor & Hachler et al. $(1987 a)$ \\
\hline CD37 & $\mathrm{Tc}^{\mathrm{s}} \mathrm{Rif}^{\mathrm{r}}$; recipient strain & Hachler et al. $(1987 a)$ \\
\hline SB1 & $\mathrm{Tc}^{\mathrm{r}} \mathrm{Rif}^{\mathrm{r}} ; 630 \times \mathrm{CD} 37$ transconjugant & This study \\
\hline SB2 & $\mathrm{Tc}^{\mathrm{r}} \mathrm{Rif}^{\mathrm{r}} ; 630 \times \mathrm{CD} 37$ transconjugant & This study \\
\hline SB3 & $\mathrm{Tc}^{\mathrm{r}} \mathrm{Rif}^{\mathrm{r}} ; 630 \times \mathrm{CD} 37$ transconjugant & This study \\
\hline FM29 & $\mathrm{Tc}^{\mathrm{r}} \mathrm{Rif}^{\mathrm{r}} ; \mathrm{BS} 1 \times \mathrm{CD} 37$ transconjugant & This study \\
\hline FM30 & Tc $^{r}$ Rifr ${ }^{r} ;$ BS $2 \times$ CD37 transconjugant & This study \\
\hline FM75 & $\mathrm{Tc}^{\mathrm{r}} \mathrm{Rif}^{\mathrm{r}} ; \mathrm{CD} 37:: \operatorname{Tn} 916$ & $\begin{array}{l}\text { P. Mullany et al., } \\
\text { unpublished }\end{array}$ \\
\hline \multicolumn{3}{|l|}{ E. coli } \\
\hline D20-15 & $\operatorname{tet} A$ & PHLS, Colindale, UK \\
\hline D20-16 & $\operatorname{tet} B$ & PHLS, Colindale, UK \\
\hline D20-6 & tetC & PHLS, Colindale, UK \\
\hline D22-2 & tetD & PHLS, Colindale, UK \\
\hline D22-14 & tetE & PHLS, Colindale, UK \\
\hline JIR741 & tetP & Abraham et al. (1988) \\
\hline $\mathrm{CGCl} 120$ & pAM120 (::Tn916) & Gawron-Burke et al. (1984) \\
\hline 2B1 & $\begin{array}{l}\text { Contains pAM } 120 \text { from which Tn916 has } \\
\text { spontaneously excised (pAM120LT) }\end{array}$ & This study \\
\hline $2 \mathrm{~A} 1$ & JM109 containing pPPM20 & This study \\
\hline 2A87 & HB 101 containing $\mathrm{pCDC} 1$ & This study \\
\hline JM109 & $\begin{array}{l}\text { recAl endA1 gyrA96 thi hsdR17 }\left(\mathrm{r}_{\mathrm{k}}^{-} \mathrm{m}_{\mathrm{k}}^{+}\right) \\
\text {supE44 relA1 } \lambda^{-} \Delta(\text { lac-proAB })\left(\mathrm{F}^{\prime} \text { traD36 proAB }\right. \\
\left.\text { lac } I^{\mathrm{q}} Z \Delta M 15\right)\end{array}$ & Yanisch-Perron et al. (1985) \\
\hline HB101 & $\begin{array}{l}\mathrm{F}^{-} h s d 20\left(\mathrm{r}_{\mathrm{B}}^{-} \mathrm{m}_{\mathrm{B}}^{-}\right) \text {supE44 ara- } 14 \lambda^{-} \text {galK12 } \\
\text { lacY1 proA2 rpsL20 xyl-5 mtl-1 recA13 }\end{array}$ & Maniatis et al. (1982) \\
\hline \multicolumn{3}{|l|}{ B. subtilis } \\
\hline CU2189 & $\mathrm{Tc}^{\mathrm{s}}$; recipient strain & Christie et al. (1987) \\
\hline BS1 & $\mathrm{Te}^{r} ; 630 \times \mathrm{CU} 2189$ transconjugant & This study \\
\hline BS2 & $\mathrm{Tc}^{\mathrm{r}} ; \mathrm{SB} 2 \times \mathrm{CU} 2189$ transconjugant & This study \\
\hline BS3 & $\mathrm{Tc} ; \mathrm{SB} 3 \times \mathrm{CU} 2189$ transconjugant & This study \\
\hline Plasmids & Description/derivation & Origin or reference \\
\hline pUC13 & Cloning vector & Yanisch-Perron et al. (1985) \\
\hline pPPM20 & $\begin{array}{l}\text { pUC13 containing a } 3.4 \mathrm{kbp} \text { insert of } C \text {. difficile } \\
\text { DNA encoding } \mathrm{Tc}^{\mathrm{r}}\end{array}$ & This study \\
\hline Homer III & $5.3 \mathrm{kbp}$ cosmid & Amersham \\
\hline pCDC1 & $\begin{array}{l}\text { Homer III containing a } 22.4 \mathrm{kbp} \text { insert of } C \text {. difficile } \\
\text { DNA encoding } \mathrm{Tc}^{r}\end{array}$ & This study \\
\hline pAM120 & Tn916::pGL101 & $\begin{array}{l}\text { Gawron-Burke \& Clewell } \\
\text { (1984) }\end{array}$ \\
\hline pAM120LT & 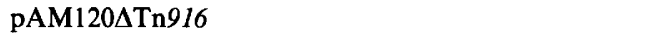 & This study \\
\hline
\end{tabular}

* Rif $r$, rifampicin resistant; Rif $^{s}$, rifampicin sensitive; $\mathrm{Tc}^{\mathrm{r}}$, tetracycline resistant; $\mathrm{Tc}^{\mathrm{s}}$, tetracycline sensitive.

Transformants were selected on plates containing ampicillin $\left(50 \mu \mathrm{g} \mathrm{ml}^{-1}\right)$ and the chromogenic substrate 5-bromo-4-chloro-3-indolyl $\beta$-D-galactopyranoside (X-Gal, Sigma). The colourless, Lac $^{-}$colonies, which contained inserts of $C$. difficile DNA, were replica-plated onto agar containing $24 \mu \mathrm{g}$ tetracycline $\mathrm{ml}^{-1}$.

Restriction enzyme analysis and transposon mutagenesis. The clone with the smallest DNA insert (pPPM20) was mapped with a variety of restriction enzymes (AccI, AvaI, BamHI, BscI, DdeI, EcoRI, EcoRV, HincII, HindIII, MboI, PstI, SmaI, SstI, TaqI, XbaI and XboI) under conditions specified by the suppliers (NBL). To localize the $\mathrm{Tc}^{\mathrm{r}}$ gene further, transposon mutagenesis using $\operatorname{Tn} 1000(\gamma \delta$ region of the $\mathrm{F}$ factor of $E$. coli $\mathrm{K} 12$ ) was performed to generate insertion mutations of pPPM20 which were no longer resistant to tetracycline. These insertions were localized by digesting independently with $\mathrm{HindIII}$ and EcoRI essentially as described by Taylor et al. (1987).

Preparation of radioactive DNA probes and hybridization procedures. DNA fragments were radiolabelled in vitro with $\left[{ }^{32} \mathrm{P}\right] \mathrm{dCTP}$ (Amersham) by the random hexamer primer method of Feinberg \& Vogelstein (1983). Colony hybridization was performed on nitrocellulose filters (NEN Research Products) by the method of Grunstein \& Hogness (1975). Further analysis of digested genomic DNA from $C$. difficile and $B$. subtilis strains was performed by Southern blots 
(Southern, 1975) using Gene-screen hybridization membranes (NEN Research Products). Hybridizations were carried out under conditions recommended by NEN Research Products. All blots were dried, and exposed to Fuji RX X-ray film at $-70^{\circ} \mathrm{C}$ for up to $14 \mathrm{~d}$.

Filter mating. Cultures were grown to mid-exponential phase $\left(\mathrm{OD}_{650}=0.45\right)$ and mixed in a donor : recipient ratio of $1: 1$ on $0.45 \mu \mathrm{m}$ cellulose nitrate filters (Whatman). The filters were placed on blood agar plates (Oxoid) and incubated anaerobically for $24 \mathrm{~h}$ at $37^{\circ} \mathrm{C}$. Transconjugants were selected on Wilkins-Chalgren agar supplemented with $7 \%(\mathrm{v} / \mathrm{v})$ defibrinated horse blood, rifampicin $\left(20 \mu \mathrm{g} \mathrm{ml}^{-1}\right.$, to inhibit the growth of the donor) and tetracycline $\left(20 \mu \mathrm{g} \mathrm{ml}^{-1}\right)$. When $C$. difficile was the recipient the plates were incubated anaerobically for $48 \mathrm{~h}$. In matings where $B$. subtilis was the recipient, transconjugants were selected on Wilkins-Chalgren agar plates supplemented with tetracycline $\left(20 \mu \mathrm{g} \mathrm{ml}^{-1}\right)$ and were incubated aerobically (to inhibit the growth of the C. difficile donor) at $37^{\circ} \mathrm{C}$ for $24 \mathrm{~h}$.

Stability of the $T c^{r}$ element. A single colony of the transconjugant FM29 was inoculated into $10 \mathrm{ml}$ Wilkins-Chalgren broth and incubated anaerobically at $37^{\circ} \mathrm{C}$. The mixture was subcultured daily for $14 \mathrm{~d}$.

Cosmid cloning. A library of genomic DNA from C. difficile strain 630 was constructed by ligating DNA fragments generated by partial cleavage with HindIII into the unique HindIII site of the $5.34 \mathrm{kbp}$ cosmid Homer III. The procedures of Maniatis et al. (1982) were followed. The chimeric cosmids were packaged in vitro using the Gigapack Plus packaging extract (Stratagene) and transduced into $E$. coli $\mathrm{HB} 101$. Transduced cells were plated directly onto solid medium containing tetracycline $\left(30 \mu \mathrm{g} \mathrm{ml}^{-1}\right)$ and 10 resistant colonies were selected for further study.

Preparation of oligonucleotides. Oligonucleotides homologous to the first 18 nucleotides of the left ( $5^{\prime}$ TAAACAAAGTATAAATTT $3^{\prime}$ ) and first 19 nucleotides of the right (5' GATAACTAGATTTTTATGC $3^{\prime}$ ) ends of $\operatorname{Tn} 916$ were prepared from the data of Clewell et al. (1988).

\section{Results and Discussion}

\section{Cloning and hybridization analysis of the $C$. difficile $T c^{r}$ determinant}

The $\mathrm{Tc}^{\mathrm{r}}$ gene of $C$. difficile strain 630 (see Table 1) was cloned into plasmid pUC13. Transformants were plated on tetracycline-containing agar, which yielded 13 tetracycline-resistant colonies out of 1200 tested. The inserts ranged in size between 3.4 and $6.0 \mathrm{kbp}$. Plasmid pPPM20 (Fig. 1) contained the smallest insert $(3.4 \mathrm{kbp})$ and was selected for further study; pPPM20 conferred $\mathrm{Tc}^{\mathrm{r}}$ on $E$. coli with an MIC of $64 \mu \mathrm{g} \mathrm{ml}^{-1}$.

The restriction map of the DNA cloned in pPPM20 was determined (Fig. 1), and mapping of a limited number of $\operatorname{Tn} 1000$ insertions showed that a $1.1 \mathrm{kbp}$ SacI-HindIII fragment is wholly within the $\mathrm{Tc}^{\mathrm{r}}$ gene. Dot-blot hybridization of the pPPM20 SacI-HindIII fragment with DNA from $E$. coli strains carrying $\mathrm{Tc}^{\mathrm{r}}$ genes tet $A-E$ and tet $M$ (Mendez et al., 1980; GawronBurke \& Clewell, 1984; Marshall et al., 1986) and the tet $P$ gene of Clostridium perfringens (Abraham et al., 1988)

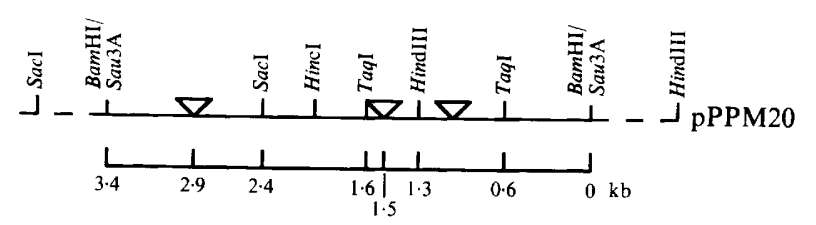

Fig. 1. Map of restriction enzyme recognition sites and $\operatorname{Tn} 1000$ insertions into plasmid pPPM20. - Cloned $C$. difficile DNA;---, vector DNA. Triangles indicate Tn1000 insertions; all abolish $\mathrm{Tc}^{r}$.

resulted in strong hybridization to the tet $M$ gene and weak non-specific hybridization to other strains, suggesting that the $C$. difficile $\mathrm{Tc}^{\mathrm{r}}$ gene is of class $\mathrm{M}$ (data not shown). Analysis of pPPM20-directed polypeptides synthesized in an in vitro transcription-translation system indicated that the plasmid encoded a protein of $68 \mathrm{kDa}$ (results not shown), which is similar to the size of the prototype TetM protein (Martin et al., 1986). Deletion of the SacI-SacI or HindIII-HindIII fragments of pPPM20 abolished the production of the $68 \mathrm{kDa}$ protein, further confirming that the SacI-HindIII fragment used in hybridization analysis is indeed wholly within the $\mathrm{Tc}^{r}$ gene. Furthermore, the tet $M$ determinant has a $1 \cdot 1 \mathrm{kbp}$ SacI-HindIII fragment. However, the $\mathrm{Tc}^{\mathrm{r}}$ gene of $C$. difficile also contains a HincII site which is not found in the tet $M$ determinant of $\operatorname{Tn} 916$.

\section{Transfer of tetracycline resistance to $C$. difficile strains and to $B$. subtilis}

Filter mating using C. difficile strains 630 and CD37 as donor and recipient, respectively, produced $\mathrm{Tc}^{\mathrm{r}}$ transconjugants at a frequency of $10^{-7}$ per donor cell; three independent transconjugants, designated SB1-SB3 were selected for further study. $\mathrm{Tc}^{\mathrm{r}}$ was also transferred from C. difficile 630 to $B$. subtilis CU2189 at a frequency of $10^{-7}$ per donor cell; transconjugant BS1 was selected for further study. $\mathrm{Tc}^{\mathrm{r}}$ previously transferred between $C$. difficile 630 and $\mathrm{CD} 37$ was further transferred from SB2 and SB3 into $B$. subtilis, at the same frequency, and BS2 and BS3 were selected from these matings. $\mathrm{Tc}^{\mathrm{r}}$ was reintroduced into $C$. difficile from $B$. subtilis $\mathrm{BS} 1$ and $\mathrm{BS} 2$ at a frequency of $10^{-8}$ per donor cell. Transconjugants FM29 and FM30 respectively were selected from these matings. B. subtilis CU2189 also became spontaneously $\mathrm{Tc}^{r}$ at a frequency of $10^{-8}$ per surviving cell. The spontaneously resistant cells had an MIC of $32 \mu \mathrm{g} \mathrm{ml}^{-1}$, the same as the transconjugants.

The transfer of $\mathrm{Tc}^{\mathrm{r}}$ from $B$. subtilis $\mathrm{BS} 1$ to $\mathrm{Tc}^{\mathrm{s}} C$. difficile RADIO-PAGE type strains $\mathrm{C}$ and D (Tabaqchali et al., 1984) was attempted but no transconjugants were obtained in any of several experiments. Similarly, there was no transfer of $\mathrm{Tn}$ 916-borne $\mathrm{Tc}^{\mathrm{r}}$ from $B$. subtilis 


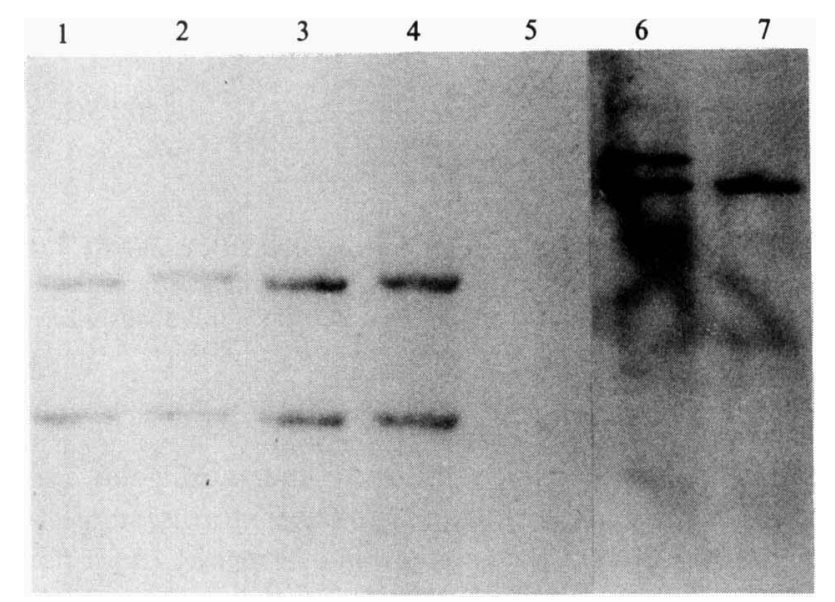

Fig. 2. Southern blot analysis of $C$. difficile genomic DNA digested with HindIII (lanes 1-5) or EcoRV (lanes 6 and 7) and probed with the ${ }^{32} \mathrm{P}$ labelled $3.4 \mathrm{kbp}$ insert of pPPM20. Lanes: 1, 630; 2, SB1 $(630 \times \mathrm{CD} 37) ; 3, \mathrm{SB} 2(630 \times \mathrm{CD} 37) ; 4, \mathrm{SB} 3(630 \times \mathrm{CD} 37) ; 5, \mathrm{CD} 37 ; 6$, $\mathrm{SB} 1 ; 7,630$.

CU2189::Tn916 to these strains, although $C$. difficile CD37 was a competent recipient in these experiments (P. Mullany and others, unpublished results).

In all matings $\mathrm{Tc}^{\mathrm{r}}$ was transferred independently of the transferable erythromycin resistance determinant, as previously observed by Wust \& Hardegger (1983).

\section{Hybridization analysis of transconjugants}

DNA from the parent and transconjugant strains of the mating $C$. difficile $630 \times C$. difficile $\mathrm{CD} 37$ was restricted with HindIII or EcoRV and probed with the $3.4 \mathrm{kbp}$ insert of plasmid pPPM20. In the HindIII-digested DNA (Fig. 2), no hybridization occurred with recipient CD37 (lane 5); DNA from the donor strain 630 (lane 1) and from transconjugants SB1, SB2 and SB3 (lanes 2-4) yielded two bands, of 3.6 and $5.5 \mathrm{kbp}$. With EcoRVdigested DNA (Fig. 2, lanes 6 and 7), the donor strain 630 produced a single $9.5 \mathrm{kbp}$ band (lane 7) while in transconjugant SB1 (lane 6) there were two bands, of $9 \cdot 5$ and $11.0 \mathrm{kbp}$. The latter bands were also detected in each of 20 further transconjugants tested (data not shown). The $11 \mathrm{kbp}$ fragment was always observed in $C$. difficile transconjugants. The results of EcoRV digests probed with the $3.4 \mathrm{kbp}$ fragment indicate that the transconjugants contain a second copy of the $\mathrm{Tc}^{\mathrm{r}}$ element (there are no EcoRV sites in the probe). The fact that only two hybridizing fragments were observed when the $3.4 \mathrm{kbp}$ probe was used against HindIII-digested genomic DNA of the transconjugants implies that the 5.5 and $3.6 \mathrm{kbp}$ fragments are adjacent and internal to the element and that the $\mathrm{Tc}^{r}$ gene spans these fragments.

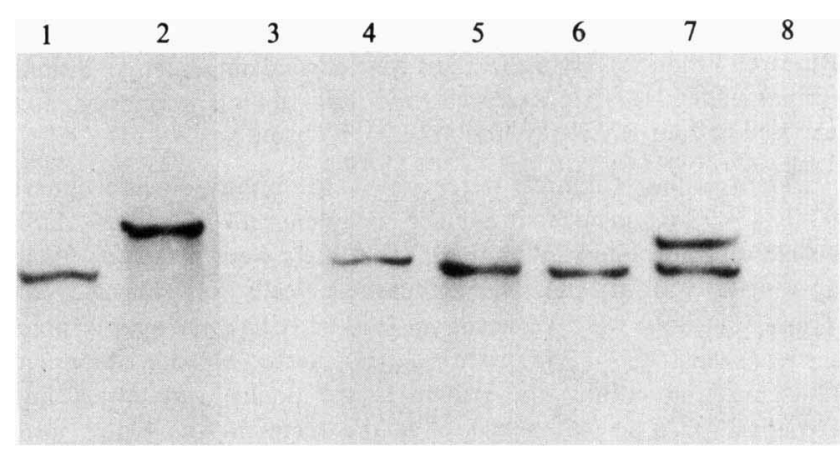

Fig. 3. Southern blot analysis of genomic DNA isolated from $C$. difficile and $B$. subtilis digested with EcoRV and probed with the ${ }^{32} \mathrm{P}$-labelled $3.4 \mathrm{kbp}$ insert of plasmid pPPM20. Lanes: 1, BS1 (630 × CU2189); 2 , BS2 (SB2 × CU2189); 3, CU2189; 4, BS3 (SB3 × CU2189); 5, 630; 6, 630; 7, FM30 (BS2 × CD37); 8, CD37.

B. subtilis genomic DNA from strains BS1, BS2 and BS3 was digested with EcoRV and probed with the $3.4 \mathrm{kbp}$ insert of pPPM20 (Fig. 3). For each transconjugant a hybridizing band of different size was produced (lanes 1,2 and 4). When DNA isolated from the spontaneously $\operatorname{Tc}^{r} B$. subtilis cells was probed with the $3.4 \mathrm{kbp}$ insert no hybridization was observed (data not shown). Ives \& Bott (1989) have shown that B. subtilis can possess a cryptic $\mathrm{Tc}^{\mathrm{r}}$ gene that only expresses on amplification or after a promoter up mutation. This gene does not hybridize with tet $M$. It is likely that we are observing the expression of such a gene.

Transfer of $\mathrm{Tc}^{\mathrm{r}}$ back into $C$. difficile $\mathrm{CD} 37$ from the $B$. subtilis transconjugants $\mathrm{BS} 1$ and $\mathrm{BS} 2$ restored the hybridization pattern, with two bands of 9.5 and $11.0 \mathrm{kbp}$ (Fig. 3, lane 7), which had been observed in EcoRV-digested DNA from matings in which both donor and recipient were $C$. difficile (Fig. 2, lane 6).

A chromosomal location for the $\mathrm{Tc}^{\mathrm{r}}$ element is implied by the fact that when the element is transferred to $B$. subtilis, fragments of variable size are observed. If the element were located on a plasmid, fragments of the same size would be expected. The data do not rule out the possibility that the element acts as a plasmid in $C$. difficile and integrates into the chromosome of $B$. subtilis. An alternative explanation of the data is that in $C$. difficile the element has a specific attachment site(s) in the chromosome, and in B. subtilis the element integrates at multiple sites. Transduction mapping using the transducing phage PBS1 will allow the position of the $\mathrm{Tc}^{\mathrm{r}}$ determinant in the chromosome of $B$. subtilis to be determined unambiguously.

The possibility also remains that the $C$. difficile $\mathrm{Tc}^{\mathrm{r}}$ element is on a plasmid that is often integrated into the chromosome. Certain strains of Streptomyces ambofaciens contain a $11 \mathrm{kbp}$ conjugative plasmid, pSAM2, 
that can be present in an integrated or a free state. The integration-excision system of this plasmid has been found to be related to that of the lambdoid phages and a requirement for two enzymes that display local homology with Xis and Int has been shown (Bocard et al., 1989a). The conjugative transposon $\operatorname{Tn} 1545$ has also been shown to contain an integration-excision system related to the lambdoid phages; furthermore, $\operatorname{Tn} 1545$ is closely related to $\mathrm{Tn} 916$, and the region required for $\mathrm{Tn} 916$ excision correlates with the gene required for $\mathrm{Tn} 1545$ excision (Poyart-Salmeron et al., 1989). As the $C$. difficile element is homologous with $95 \%$ of $\mathrm{Tn} 916$ it is also likely to contain a related integration excision system. pSAM2 integration involves a site-specific recombination event within a $58 \mathrm{bp}$ att sequence present on both plasmid and chromosome. The att site is found in three distantly related Streptomyces strains and a wide host range within the genus Streptomyces is implied (Bocard et al., 1989b). The conjugative transposons $\operatorname{Tn} 916$ and $\operatorname{Tn} 1545$ do not appear to require long att sequences in most hosts. This probably reflects their ability to recognize degenerate $a t t$ sites in most species. However, in $C$. difficile both the $\mathrm{Tc}^{\mathrm{r}}$ element and Tn916 (P. Mullany and others, unpublished results) enter the genome at specific sites. The inability to transfer the $C$. difficile element and Tn916 into some strains of $C$. difficile may be due to the lack of a suitable attachment site which is required by and common to both elements.

Work by Volk et al. (1988) has shown that bidirectional transfer of $\mathrm{Tn} 916$ between Clostridium tetani and Streptococcus faecalis can occur in vitro. Hachler et al. $(1987 b)$ have shown that $C$. difficile is able to transfer erythromycin resistance to Staphylococcus aureus in vitro via a conjugation-like mechanism, possibly on a conjugative transposon. Our results extend the above observations to include bi-directional transfer of $\mathrm{Tc}^{\mathrm{r}}$ between $C$. difficile and $B$. subtilis; this observation represents the first demonstration that $C$. difficile can act as a recipient in intergeneric crosses, thus paving the way for a more extensive genetic analysis of this species.

$\mathrm{Tc}^{\mathrm{r}}$ is widespread in bacteria and the tet $M$ gene has been found in many different genera (recently reviewed by Salyers et al., 1990). The conjugative transposons are often responsible for mediating this resistance type. This communication demonstrates a further extension of the host range of these promiscuous elements.

\section{Stability of the $T c^{r}$ element}

After daily subculture for $14 \mathrm{~d}$ all of 100 colonies tested from the final subculture were resistant to tetracycline.

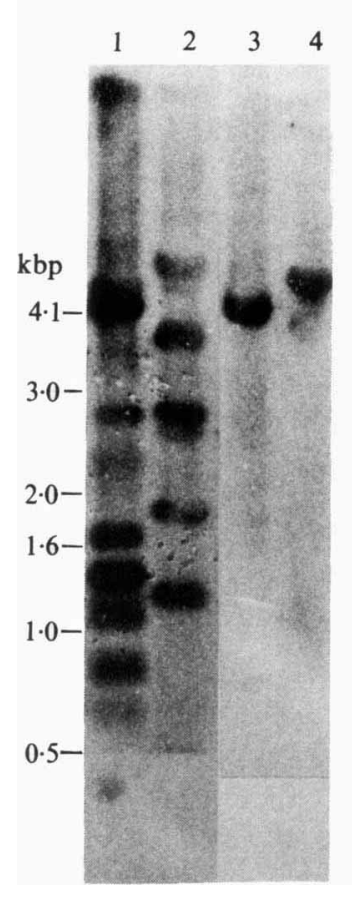

Fig. 4

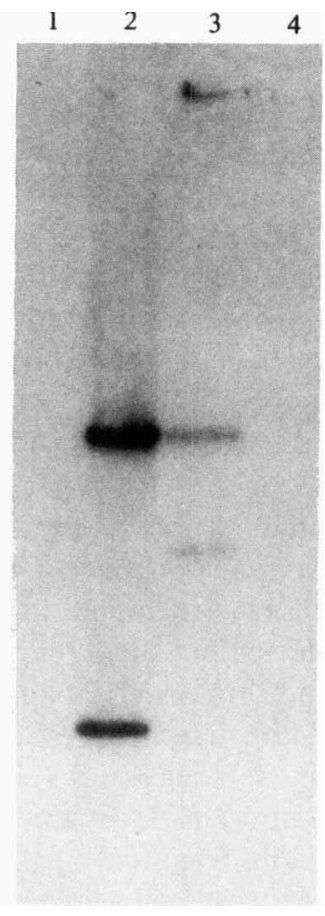

Fig. 5
Fig. 4. Southern blot analysis of plasmid DNA digested with HincII and probed with ${ }^{32} \mathrm{P}$-labelled genomic DNA isolated from FM30 (lanes 1 and 2) and CD37 (lanes 3 and 4). Lanes: 1, pCDC1; 2, pAM120;3, pCDC1; 4, pAM120.

Fig. 5. Southern blot analysis of $C$. difficile genomic DNA digested with HindIII and probed with an oligonucleotide recognizing the right end of $\mathrm{Tn} 916$ (lanes 1 and 2) and an oligonucleotide recognizing the left end of Tn916 (lanes 3 and 4). Lanes: 1 and 4, SB1; 2 and 3, FM75.

\section{Relationship of Tn916 to the C. difficile Tr element}

DNA from $C$. difficile 630 was partially digested with HindIII and cloned into the unique HindIII site of the $5.34 \mathrm{kbp}$ cosmid Homer III. The Tc $\mathrm{Tc}^{\mathrm{r}}$ clones had inserts of approximately $22.4 \mathrm{kbp}$, and all produced identical patterns on digestion with HindIII (data not shown). One cosmid, pCDC1 (Table 1), was selected for further study.

Gawron-Burke \& Clewell (1984) have shown that pAM120 when digested with HincII generates five Tn916 internal and two junction fragments. Some properties of $\operatorname{Tn} 916$ have been mapped to these fragments (Senghas et al., 1988). To determine whether Tn916 and the C. difficile element had any HincII sites in common, genomic DNA (from the transconjugant FM30 and the recipient strain CD37) was radiolabelled and used to probe HincII-restricted pAM120 and pCDC1 (Fig. 4). HincII treatment of $\mathrm{pCDC1}$ generates fragments of $6 \cdot 0,4 \cdot 4,2 \cdot 8,2 \cdot 2,1 \cdot 6,1 \cdot 4,1 \cdot 1,0 \cdot 7$ and $0.6 \mathrm{kbp}$. Of these, all except the 6.0 and $2.1 \mathrm{kbp}$ fragments show 
some homology with FM30 (Fig. 4, lane 1); the fragments of 4.4 and $1.3 \mathrm{kbp}$ show the strongest hybridization to the probe, possibly indicating double bands at these points. There is no homology to the vector sequences (results not shown).

Digestion of pAM120 with HincII generates fragments of $5.4,4.8,3.7,2.8,2.7,1.8,1.2$ and $0.4 \mathrm{kbp}$ (Senghas et al., 1988). All the fragments show some homology to the probe (Fig. 4, lane 2) but the $2.7 \mathrm{kbp}$ fragment shows only very poor homology. This fragment is likely to be from pAM120LT, a derivative of pAM120 lacking Tn916 due to spontaneous deletion (see Table 1), which is always present in preparations of pAM120 (Gawron-Burke \& Clewell, 1984). The fifth Tn916 internal fragment, at $0.4 \mathrm{kbp}$, was too small to be detected in these experiments. The only hybridizing band that PAM120 and pCDC1 have in common is the $2.8 \mathrm{kbp}$ fragment. When CD37 was used as the probe (Fig. 4, lanes 3 and 4) hybridization was observed to the $4.4 \mathrm{kbp}$ HincII fragment of pCDCl (lane 3 ) and to the $5.4 \mathrm{kbp}$ fragment of pAM120 (lane 4).

At least $10.4 \mathrm{kbp}$ of $\mathrm{pCDC1}$ appears to be part of the $\mathrm{Tc}^{\mathrm{r}}$ element as this hybridizes specifically to DNA from FM30; 4.1 kbp hybridizes to DNA from CD37. CD37 differs from FM30 only by the absence of the $\mathrm{Tc}^{\mathrm{r}}$ element. Hybridization of genomic DNA of the $\mathrm{Tc}^{\mathrm{s}} C$. difficile recipient $\mathrm{CD} 37$ to a fragment of $\mathrm{Tn} 916$ has also been demonstrated by Hachler et al. (1987a). The reason for this homology cannot be explained at present. However, it is possible that CD37 once contained a functional Tn916-like element which could have undergone an aberrant transposition event, leaving a truncated element in the genome. This could act as a substrate for homologous recombination, explaining the site-specificity of the element as observed in $C$. difficile.

In order to characterize further the relationship between $\operatorname{Tn} 916$ and the $C$. difficile element, HindIII digests of genomic DNA from CD37 containing Tn916 (FM75) and CD37 containing the $C$. difficile element (SB1) were probed with oligonucleotides homologous to the left and right ends of Tn916. Fig. 5 shows FM75 DNA probed with an oligonucleotide which recognizes the right end of $\operatorname{Tn} 916$ (lane 2) and an oligonucleotide which recognizes the left end of Tn916 (lane 3). Hybridization is seen to two fragments in each lane, indicating that there are two copies of Tn916 in FM75. Lanes 1 and 4 in Fig. 5 contain DNA from SB1 digested with HindIII and probed with the right (lane 1) and left (lane 4) ends of $\operatorname{Tn} 916$. No hybridization was observed to this DNA. The fact that the $C$. difficile element shows no hybridization to oligonucleotides homologous to both ends of Tn916 shows further differences between the two elements. The nucleotide sequence of the extremities of Tn916 and the only other conjugative transposon (from a
Gram-positive host) for which data are available, Tn 1545 , is almost identical for at least $250 \mathrm{bp}$ (Caillaud \& Courvalin, 1987; Clewell et al., 1988). Our results suggest that the $C$. difficile element is likely to be a conjugative transposon related to but distinct from $\operatorname{Tn} 916$ and $\operatorname{Tn} 1545$. Further work is required to establish exactly how close the relationship is.

We thank H. Hachler, J. Rood and J. Adsit for providing strains, and John Keyte for providing oligonucleotides. This work was supported by the Wellcome Trust and the Joint Research Board, St Bartholomew's Hospital.

\section{References}

ABRAHAM, L. J., BerRyam, D. I. \& RoOD, J. I. (1988). Hybridization analysis of the class $\mathrm{P}$ Tet determinant from the Clostridium perfringens R-plasmid pCW3. Plasmid 19, 113-120.

Bartlett, J. G., Chang, T. W., Gurwith, M., Gorbach, S. L. \& ONDERDONK, A. B. (1978). Antibiotic-associated colitis due to toxinproducing clostridia. New England Journal of Medicine 239, 531-534.

BIRNBoIM, H. C. \& DoLY, J. (1979). A rapid extraction procedure for screening recombinant plasmid DNA. Nucleic Acids Research 7, 1514-1523.

Bocard, F., Smokvina, T., Pernodet, J.-L., Friedmann, A. \& GUERINEAU, M. $(1989 a)$. The integrated conjugal plasmid pSAM2 of Streptomyces ambofaciens is related to temperate bacteriophages. EMBO Journal 8, 973-980.

Bocard, F., Smokvina, T., Pernodet, J.-L., Friedmann, A. \& GUERINEAU, M. $(1989 \mathrm{~b})$. Structural analysis of loci involved in pSAM2 site-specific integration in Streptomyces. Plasmid 21, 59-70.

Caillaud, F. \& Courvalin, P. (1987). Nucleotide sequence of the ends of the conjugative transposon Tn1545. Molecular and General Genetics 209, 110-115.

Christie, P. J., Korman, R. Z., Zahler, S. A., Adsit, J. C. \& DunNY, G. M. (1987). Two conjugation systems associated with Streptococcus faecalis plasmid pCF10: identification of a conjugative transposon that transfers between $S$. faecalis and Bacillus subtilis. Journal of Bacteriology 169, 2529-2536.

Clewell, D. B. \& Gawron-Burke, C. (1986). Conjugative transposons and the dissemination of antibiotic resistance in streptococci. Annual Review of Microbiology 40, 635-659.

Clewell, D. B., Flannagan, S. E., IKe, Y., Jones, J. M. \& GawronBURKE, C. (1988). Sequence analysis of the termini of conjugative transposon Tn916. Journal of Bacteriology 170, 3046-3052.

FeinberG, A. P. \& Vogelstein, B. (1983). A technique for radiolabelling DNA restriction endonuclease fragments to high specific activity. Annals of Biochemistry 132, 6-13.

GAWRON-BuRKe, C. \& CleWELl, D. B. (1984). Regeneration of insertionally inactivated streptococcal DNA fragments after excision of transposon $\mathrm{Tn} 916$ in Escherichia coli: strategy for targeting and cloning of genes from Gram-positive bacteria. Journal of Bacteriology 159, 214-221.

GeORGE, R., Symonds, J. M. \& Dimock, F. (1978). Identification of Clostridium difficile as a cause of pseudomembranous colitis. British Medical Journal i, 695.

GrunsteIn, M. \& Hogness, D. S. (1975). Colony hybridization: a method for the isolation of cloned DNAs that contain a specific gene. Proceedings of the National Academy of Sciences of the United States of America 72, 3961-3965.

HACHLER, H., KAYSER, F. H. \& Berger-BACHI, B. (1987a). Homology of a transferable tetracycline resistance determinant of Clostridium difficile with Streptococcus (Enterococcus) faecalis transposon Tn916. Antimicrobial Agents and Chemotherapy 31, 1033-1038. 
HACHLER, H., KAYSER, F. H. \& BERGER-BACHI, B. (1987b). Genetic characterisation of a Clostridium difficile erythromycin-clindamycin resistance determinant that is transferable to Staphylococcus aureus. Antimicrobial Agents and Chemotherapy 31, 1039-1045.

HANAHAN, D. (1985). Technique for transformation of Escherichia coli. In DNA Cloning : a Practical Approach, vol. 1,pp. 109-135. Edited by D. M. Glover. Oxford: IRL Press.

IVES, C. L. \& BotT, K. F. (1989). Cloned Bacillus subtilis chromosomal DNA mediates tetracycline resistance when present in multiple copies. Journal of Bacteriology 171, 1801-1810.

Larson, H. E. \& Price, A. B. (1977). Pseudomembranous colitis: presence of a clostridial toxin. Lancet ii, 1312-1314

Maniatis, T., Fritsch, E. F. \& SambrooK, J. (1982). Molecular Cloning: a Laboratory Manual. Cold Spring Harbor, NY: Cold Spring Harbor Laboratory.

Marshall, B., Morrisy, S., Flyn, P. \& Levy, S. (1986). A new tetracycline resistance determinant, class $\mathrm{E}$, isolated from Enterobacteriaceae. Gene 50, 111-117.

Martin, P., Trieu-Cuot, P. \& Courvalin, P. (1986). Nucleotide sequence of the tet $M$ tetracycline resistance determinant of the streptococcal conjugative shuttle transposon Tn1545. Nucleic Acids Research 14, 7047-7058.

Mendez, B., Tachilbana, C. \& Levy, S. B. (1980). Heterogeneity of tetracycline resistance determinants. Plasmid 3, 99-108.

Nakamura, S., Serikaur, T., Mikaura, S., NaKaskio, S., Yamakowa, K. \& Nishida, S. (1981). Agglutination toxicity and sorbitol fermentation of C. difficile. Microbiology and Immunology 25, 836-870.

Pierce, P. F., Wilson, R. \& Silva, J. (1982). Antibiotic-associated pseudomembranous colitis: an epidemic investigation of a cluster of cases. Journal of Infectious Diseases 145, 269-274.

Poyart-Salmeron, C., Trieu-Cuot, P., Calier, C. \& Courvalin, P. (1989). Molecular cloning of two proteins involved in the excision of the conjugative transposon $\operatorname{Tn} 1545$ : homology with other sitespecific recombinases. EMBO Journal 8, 2425-2433.
Salyers, B. S., Speer, B. S. \& Shoemaker, N. B. (1990). New perspectives in tetracycline resistance. Molecular Microbiology 4, 151-156.

Senghas, E., Jones, J. M., Yamamoto, M., Gawron-Burke, C. \& ClewELl, D. B. (1988). Genetic organisation of the bacterial conjugative transposon Tn916. Journal of Bacteriology 170, 245-249.

SOUTHERN, E. M. (1975). Detection of specific sequences among DNA fragments separated by gel electrophoresis. Journal of Molecular Biology 98, 503-517.

TabaQchali, S., O'Farrell, S., Holland, D. \& Silman, R. (1984) Typing scheme for Clostridium difficile: its application in clinical and epidemiological studies. Lancet i, 935-938.

TaYlor, D. E., Hiratsuka, K., Ray, H. \& Manavathu, E. K. (1987). Characterization and expression of a cloned tetracycline resistance determinant from Campylobacter jejuni plasmid pUA466. Journal of Bacteriology 169, 2984-2989.

VoLK, W. A., BIZzINI, B. \& JoNEs, K. R. (1988). Inter and intrageneric transfer of $\operatorname{Tn} 916$ between Streptococcus faecalis and Clostridium tetani. Plasmid 19, 255-259.

WREN, B. W. \& TABAQCHALI, S. (1987). Restriction endonuclease DNA analysis of Clostridium difficile. Journal of Clinical Microbiology 25, 2402-2404.

WUST, J. N. \& HARDEGGER, U. (1983). Transferable resistance to clindamycin, erythromycin and tetracycline in Clostridium difficile. Antimicrobial Agents and Chemotherapy 23, 784-786.

Wust, J. N., Sullivan, N. M., Hardegger, U. \& Wilkins, T. D (1982). Investigation of an outbreak of antibiotic-associated colitis by various typing methods. Journal of Clinical Microbiology 16, 10961101.

Yanisch-PerRon, G., VieIRA, J. \& Messing, J. (1985). Improved M13 phage cloning vectors and host strains: nucleotide sequences of the M13 mp18 and pUC19 vectors. Gene 33, 103-119. 